\title{
A conceptual assessment model to identify phase of industrial cluster life cycle in Indonesia
}

\author{
Naniek Utami Handayani ${ }^{1,2}$, Andi Cakravastia ${ }^{1}$, Lucia Diawati ${ }^{1}$, Senator Nur Bahagia ${ }^{1}$ \\ ${ }^{1}$ Study Program of Industrial Engineering, Bandung Institute of Technology, ${ }^{2}$ Department of Industrial \\ Engineering, Diponegoro University (INDONESLA) \\ naniekh@yahoo.com; andi@mail.ti.itb.ac.id; diawati@yahoo.com; senaton@mail.ti.itb.ac.id
}

Received December 2011

Accepted June 2012

\section{Abstract:}

Purpose: The purpose of this research is to develop an assessment model to identify phase of industrial cluster life cycle which comprises definition of the cycle phases, identification of assessment components, and characterization of each phase of cluster life cycle.

Design/methodology/approach: This research uses the Delphi Method to develop the conceptual model i.e. define phases of cluster life cycle and identify assessment components, and design typology of cluster life cycle.

Findings: The findings of this research are assessment indicators and typology of cluster life cycle. The proposed indicators used to assess industrial cluster phases are (i) concentration of industry, (ii) market accessibility, (iii) completeness of actors, and (iv) collaboration of stakeholders.

Research limitations/implications: This study developed a conceptual model based on expert opinion in Indonesia. Given the limitations of experts in this field in Indonesia, it is necessary to develop advanced research involving more experts and if possible, to involve experts outside Indonesia.

Practical implications: On practical level, the assessment result could be used to evaluate and improve the condition of industrial clusters and helplocal and central 
government to formulate policy interventions in accordance with each phase of cluster life cycle.

Originality/value: The paper provides an assessment conceptual model to identify phases of industrial cluster life cycle, which include definition phases, assessment components and typology of each phase of cluster life cycle based on assessment criteria. Research in this field was rarely done by the other researchers.

Keywords: assessment conceptual model, identify phase, industrial cluster, life cycle, policy interventions

\section{Introduction}

Industrial clusters are geographic concentrations of interconnected companies, specialized suppliers, service providers, firms in the related industries, and associated institutions in a particular field that compete but also cooperate (Porter, 1990). According to Schmitz \& Musyck (1994), an industrial cluster is a group of similar industries in a particular location that arises from the existence of workers with skills in common or the common interests of business actors. The industrial cluster is an alternative approach to improve industrial competitiveness in a region. It focuses on developing an industrial value-added chain from the upstream to downstream of the industries, involving a wide scope of business activities. A cluster's condition is influenced by various factors where the cluster is evolving, such as cultural, social, and historical factors, educational level of business owners, infrastructure availability, composition of business actors, and others. An industrial cluster has a role in the development of industrial competitiveness, i.e. cluster increase productivity (efficiency), cluster encourages and accelerates innovation, and cluster facilitates commercialization (Porter, 2008).

In Indonesia, the alteration in socio-economic conditions and politics has encouraged the government to implement regional autonomy. As a consequence, policy making has to be transferred from central to local government. This has also brought several problems, and a situation that is contradiction to the cluster concept as an approach for industrial development, based on regional and crossindustrial sectors. The problem is as follows (Ministry of Industry, 2001). First, the policy transition from central to local governments was not smooth due to a lack of information during the transformation process. Local governments lacked 
understanding of the policy set by central government, leading to the failure of policy implementation. Second, the lack of government understanding as policy maker regarding several factors that could accelerate the cluster growth.

These are:

- The difference between prospective and non-prospective industrial clusters for growth

- The characteristics of each industrial cluster

- The lack of a uniform policy instrument in the development of industrial clusters

- The prerequisite learning process by stakeholders (actors) needed for development of industrial clusters

- Basic barriers to industrial cluster development (Tambunan \& Hillebrand, 2001)

- Industrial cluster growth phases (Menzel \& Fornahl, 2007, 2009; Bianchi, Miller \& Bertini, 1997; Altena \& Heijman, 2007).

Reflecting on the success of some countries in Europe on industrial cluster development, since 2005, the Government set the industrial cluster approach as a strategy for industrial development in Indonesia. However, this policy setting is not without obstacles. The facts show that the conditions of each cluster are different. This is caused the differences characteristics of each phases of industrial cluster life cycle (Andersson et al, 2004; Rocha, 2004; Lorenzen, 2005; Menzel \& Fornahl, 2006; Handayani, Siregar, Diawati, \& Cakravastia, 2009; Handayani, Diawati, Cakravastia \& Nur Bahagia, 2010). The difference phases of industrial clusters have an impact on different policy interventions that should be set by the Government (Rocha, 2004; Lorenzen, 2005; Menzel \& Fornahl, 2006; Handayani et al. 2009; Handayani et al., 2010). For illustration, a few papers explain a policy intervention that was set in the early and maturation phases of cluster life cycle. In early phase, the government should be formulating the policy interventions that can strengthen the process and quicken the formation of the critical mass. In the maturation phase, the clusters need policy interventions that encourage openness and innovation that maintain the cluster was not become decline (Azis, Richardson \& Azis, 2011). 
The formulation of policies intervention for industrial cluster growth should be appropriate with the conditions of each cluster. It requires an understanding of the different phase of industrial cluster life cycle (Rocha, 2004; Lorenzen, 2005; Menzel \& Fornahl, 2007; Handayani et al., 2009; Handayani et al., 2010). Consequently, we need to identify the phases of industrial clusters life cycle in order to ascertain their underlying conditions. By this assessment, we can be a desire to improve the current condition and then stipulate the appropriate policies intervention for industrial cluster growth. Moreover, the government could also examine the effectiveness and efficiency of policies intervention that have been done. The assessment is needed to provide information for decision makers who are then able to carry out regulatory actions upon the core system being managed.

There are several studies on cluster life cycle. Cluster life cycle has been classified into five categories: (i) agglomeration, (ii) emerging, (iii) developing, (iv) mature, and ( $v$ ) transformation (Andersson, Serger, Sorvik \& Hansson, 2004). The cluster can be classified into three phases, namely: embryo, consolidated, and mature (Bianchi et al., 1997; Cortright, 2006). Cluster life cycle could be divided into existing, emerging, and potential (Feser, 2004). In this model, we separate industrial cluster life cycle into four phases, namely agglomeration, emerging, developing, and mature, that refers to Andersson et al. (2004). It was caused this definition is most comprehensive for describing the cluster life cycle (Handayani et al., 2009, 2010).

The reviewers of many papers explained that concentration of industry can be used to identify industrial cluster growth. This is measured by the location quotient (LQ) that describes the industrial growth in a particular region (Barkley \& Henry, 1997; Maggioni, 2002, 2004; Mayer, 2003; Shields, Barkley \& Emery, 2004; Cortright, 2006; Maggioni \& Riggi, 2008). Moreover, industrial cluster growth could also be assessed by market accessibility, which is the key factor to improving the industrial clusters competitiveness. It can be measured by the clusters ability to gain access to global markets (Nadvi \& Barrientos, 2004; Bergman, 2007). Competitiveness will thus stimulate the industrial cluster growth (Porter, 1990; Bergman, 2007). LQ and market more appropriately used to measure the growth of specific industrial sector in a certain area; but, it could not describe industrial cluster dynamic that is actors and collaboration and discriminate the phases. Some studies explained the assessment dimensions that discriminate the industrial cluster phases. Yet, these studies only discus in the field of assessment conceptual model, and there is no research that develop an assessment model for identifying phases of industrial cluster life cycle. Porter (1990) and Andersson et al. (2004) explain that life cycle is 
identified by type of actor and collaboration. Maggioni (2002, 2004) and Maggioni and Riggi (2008) further explained that the life cycle in a specific industrial cluster can be described by focusing on the number of incumbents and time. Menzel \& Fornahl (2007, 2009) identified industrial cluster life cycle by using direct and systemic dimensions, both qualitative and quantitative. The main indicators used are a number of firms, total employment, organisational conditions, knowledge, competencies, networks, and network condition, such as the value chain, and synergies. They did not suggest an assessment model for identifying phase of industrial cluster life cycle.

For developing the industrial cluster, we need to know the position of each cluster in their life cycle. Understanding these phases requires assessment model that should accommodate the discriminant factors to identify phase of industrial cluster life cycle. For development assessment model, we need to design typology of each phase of cluster life cycle. These typologies are ideal characteristics of each phase of cluster life cycle, as a basis to develop assessment model. Based on the previous review, it can be concluded that there is no research related design typology and assessment model to identify phase of cluster life cycle. The purpose of this research is develop an assessment conceptual model to identify phase of industrial cluster life cycle, involve define phase of life cycle, identify of assessment components, and design typology of cluster life cycle.

The organization of this paper is as follows. Section 1 is the introduction. Section 2 contains research methodology and the Delphi Method. Section 3 describes the assessment model to identify phases of industrial cluster life cycle. Section 4 explains the discussion. Section 5 presents conclusions and future research.

\section{Cluster life cycle: A literature review}

\subsection{Cluster life cycle conception}

Reviewing the general agreement that clusters has a life cycle, which refers from product life cycle and industry life cycle theories. Some studies describe clusters by their age and growth, often either as emerging (many new firms, rapid growth, frequent changes in firms and products), established or mature (fewer, larger firms, slower growth, fewer changes in products), or declining (stagnant or declining employment growth, more firm deaths than births, few or no changes in products). The cluster life cycle also contains the opportunity that clusters may reinvent or redefine themselves as markets and technology change. Such reinvention or redefinition may reinvigorate a declining cluster (Bianchi et al., 1997). 
It because of continual changes in markets, competition, and technology, clusters tend to evolve continually, with some clusters ebbing or dying even as new ones form and grow. There are some factors that drive their success change during clusters evolve. The economic factors that give rise to a cluster can be very different from those that keep the cluster going. After a cluster is formed, positive feedback effects help drive cluster growth. However, the initial market or technological breakthroughs that cause a cluster to form are unpredictable (Bresnahan, Gambardella \& Saxenian, 2001).

\subsection{The Phases and characteristics of each phase of cluster life cycle}

The important element of cluster is its structural character that used to organize the cluster for long term. There are certain characteristic patterns in each phase of clusters life cycle. Many studies have been explained characteristics of each phase of industrial cluster life cycle, as in Table 1.

\begin{tabular}{|c|c|c|c|c|c|}
\hline \multirow{2}{*}{ Researcher } & \multicolumn{5}{|c|}{ Definition } \\
\hline & Pre-cluster & Arise & Growing & Mature & Alteration \\
\hline \multirow[b]{2}{*}{$\begin{array}{l}\text { Andersson } \\
\text { et al., } 2004\end{array}$} & Agglomeration & Emerging & Developing & Mature & Transformation \\
\hline & $\begin{array}{l}\text { There are a } \\
\text { few firms in } \\
\text { particular } \\
\text { location }\end{array}$ & $\begin{array}{l}\text { The actor } \\
\text { begin a } \\
\text { collaboration }\end{array}$ & $\begin{array}{l}\text { New firms or } \\
\text { actor join the } \\
\text { cluster } \\
\text { Formalize the } \\
\text { institution of } \\
\text { collaboration }\end{array}$ & $\begin{array}{l}\text { The critical mass } \\
\text { establish } \\
\text { There are } \\
\text { relationship with } \\
\text { the other cluster }\end{array}$ & $\begin{array}{l}\text { Transform to } \\
\text { new cluster } \\
\text { cause } \\
\text { specialization }\end{array}$ \\
\hline \multirow{3}{*}{$\begin{array}{l}\text { Menzel \& } \\
\text { Fornahl, } \\
2007,2009\end{array}$} & & Emerging & Growing & Sustaining & Declining \\
\hline & & $\begin{array}{l}\text { A few firms } \\
\text { and labor }\end{array}$ & $\begin{array}{l}\text { Increasing } \\
\text { number of firm } \\
\text { and labour }\end{array}$ & $\begin{array}{l}\text { Number of firms } \\
\text { and labour were } \\
\text { stagnant }\end{array}$ & $\begin{array}{l}\text { Number of } \\
\text { firms and } \\
\text { labour were } \\
\text { decline }\end{array}$ \\
\hline & & $\begin{array}{l}\text { There is no } \\
\text { collaboration } \\
\text { No chance } \\
\text { for } \\
\text { cooperation }\end{array}$ & $\begin{array}{l}\text { A common } \\
\text { perception } \\
\text { Chance for } \\
\text { cooperation }\end{array}$ & $\begin{array}{l}\text { Cluster has form a } \\
\text { specific area }\end{array}$ & $\begin{array}{l}\text { Negative } \\
\text { sentiment } \\
\text { about cluster } \\
\text { A few chance } \\
\text { for cooperation }\end{array}$ \\
\hline \multirow[b]{2}{*}{$\begin{array}{l}\text { Maggioni, } \\
2002,2004\end{array}$} & & Birth/take of & Golden age & Maturity & \\
\hline & & $\begin{array}{l}\text { The growth } \\
\text { influence by } \\
\text { benefit } \\
\text { colocation } \\
\text { Exogenous } \\
\text { growth }\end{array}$ & $\begin{array}{l}\text { Economic } \\
\text { agglomeration is } \\
\text { important role in } \\
\text { encourage } \\
\text { growth and } \\
\text { transformation } \\
\text { cluster structure }\end{array}$ & $\begin{array}{l}\text { Internationalization } \\
\text { cluster } \\
\text { Technology } \\
\text { leadership } \\
\text { Begin to decline }\end{array}$ & \\
\hline \multirow[b]{2}{*}{$\begin{array}{l}\text { Bianchi et } \\
\text { al., } 1997\end{array}$} & Embryo & & Consolidation & Mature & \\
\hline & $\begin{array}{l}\text { A location } \\
\text { with a few of } \\
\text { firms }\end{array}$ & & $\begin{array}{l}\text { There is } \\
\text { innovation and } \\
\text { policy } \\
\text { intervention } \\
\text { A difficult to } \\
\text { innovation }\end{array}$ & $\begin{array}{l}\text { High capacity of } \\
\text { innovation } \\
\text { Competitive in } \\
\text { global market } \\
\text { High value added } \\
\text { Specialization } \\
\text { Cooperation with } \\
\text { the other cluster }\end{array}$ & \\
\hline
\end{tabular}




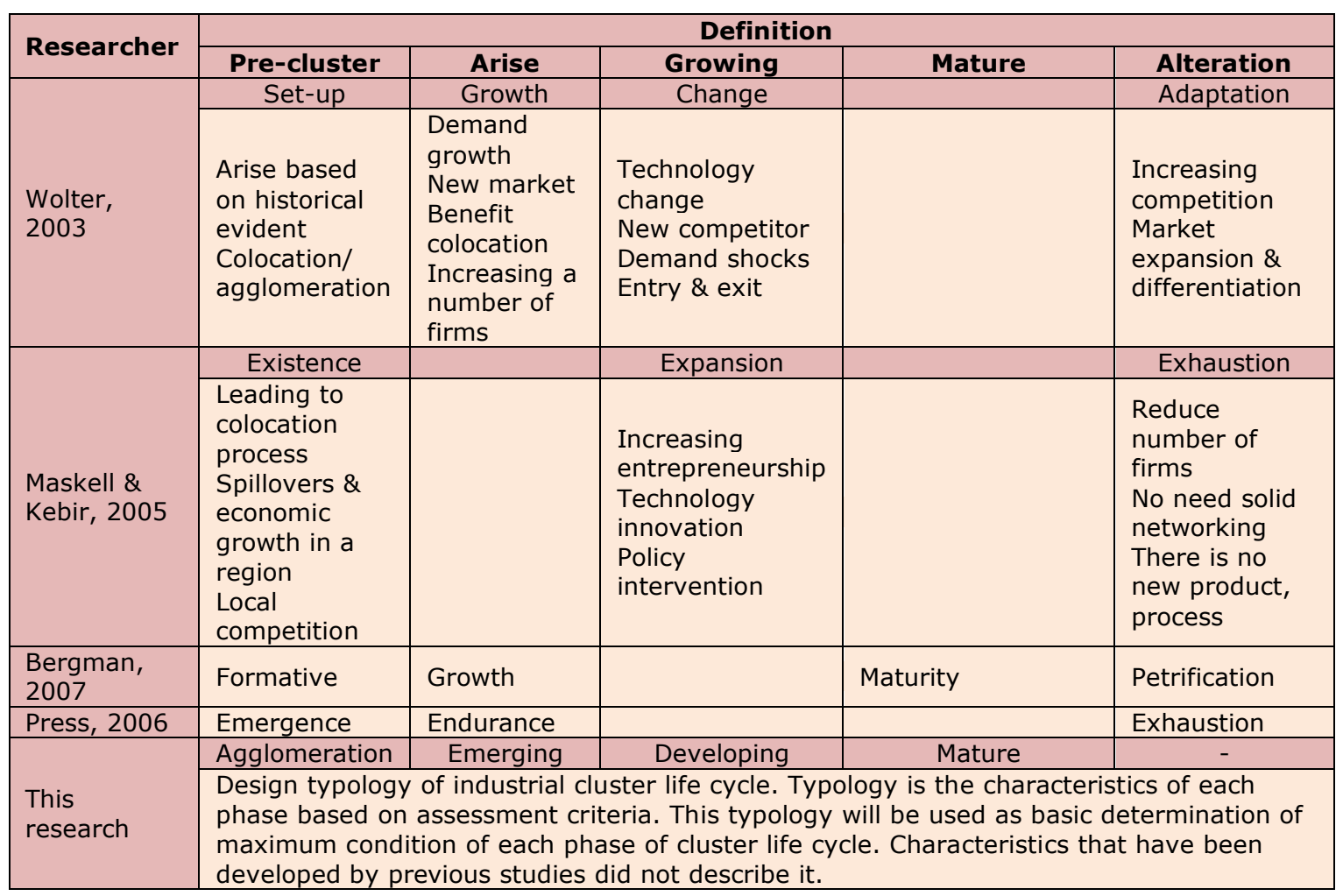

Table 1. Definition and characteristics of industrial cluster life cycle

\subsection{The assessment components to identify phase of cluster life cycle}

Some researchers use the concentration of industry and market accessibility to assess industrial cluster growth. However, these dimensions cannot discriminate the phase of industrial cluster life cycle. Based on the industrial cluster definitions (Porter, 1990), we concluded that industrial clusters is formed by the completeness of actors i.e. type of actor who joins in cluster and the collaboration between stakeholders. Thus, we enhance the completeness of actors and collaboration of stakeholders as dimensions to identify phase of cluster life cycle. Next, we present the dimensions that used to identify phase of industrial clusters life cycle, as in Table 2.

Industrial cluster growth in a particular region can be explained by their concentration of industry (Barkley \& Henry, 1997; Maggioni, 2002, 2004; Mayer, 2003; Shields et al., 2004; Cortright, 2006; Maggioni \& Riggi, 2008). Index LQ explains that industries have a comparatively larger (or smaller) presence in the local economy. If a LQ equal to 1.0 means that the share of employment in a particular industry in a region is exactly the same as the share of employment in the same industry nationally. If the LQ is larger than 1.0 the local share of employment in a particular industry exceeds the national share of employment in the same industry. It means that locally the industry is more concentrated and 
might have a comparative advantage and vice versa (Mayer, 2003). So, we can conclude that the industries in the region are growing. Therefore, we use the LQ to measure industrial cluster growth. However, LQ more appropriately used to measure the growth of specific industrial sectors in a certain area (Woodward \& Guimarães, 2009). High LQ value is not necessarily indicate an industrial clusters growth (Porter, 1990).

\begin{tabular}{|c|c|c|c|c|}
\hline \multirow{2}{*}{ Researcher } & \multicolumn{4}{|c|}{ Dimensions } \\
\hline & Cluster Size & Market & Actor & Collaboration \\
\hline Porter, 1990 & & $\begin{array}{l}\text { Demand } \\
\text { Market } \\
\text { accessibility }\end{array}$ & Type of actors & $\begin{array}{l}\text { Collaboration } \\
\text { Competition }\end{array}$ \\
\hline Kotler et al., 1997 & & & $\begin{array}{l}\text { Type of actors in } \\
\text { vertical \& horizontal } \\
\text { linkage }\end{array}$ & \\
\hline $\begin{array}{l}\text { Nadvi \& Barientos, } \\
2004\end{array}$ & & $\begin{array}{l}\text { Market } \\
\text { accessibility }\end{array}$ & & \\
\hline Bergman, 2007 & Number of firms & $\begin{array}{l}\text { Market } \\
\text { accessibility }\end{array}$ & & Networking \\
\hline $\begin{array}{l}\text { Andersson et al., } \\
2004\end{array}$ & & & Type of actor & Collaboration \\
\hline Cortright, 2006 & $\begin{array}{l}\text { Concentration of } \\
\text { industry/LQ } \\
\text { Number of } \\
\text { employment } \\
\text { Input output } \\
\text { relationship } \\
\end{array}$ & & & \\
\hline Mayer, 2003 & $\begin{array}{l}\text { Concentration of } \\
\text { industry/LQ } \\
\text { Employment growth }\end{array}$ & & & \\
\hline $\begin{array}{l}\text { Shileds et al., 2004; } \\
\text { Barkley \& Henry, } \\
1997\end{array}$ & $\begin{array}{l}\text { Concentration of } \\
\text { industry/LQ }\end{array}$ & & & \\
\hline Wolter, 2003 & Number of firms & & & \\
\hline $\begin{array}{l}\text { Maggioni \& Riggi, } \\
2008\end{array}$ & $\begin{array}{l}\text { Cluster size (LQ) } \\
\text { New entry } \\
\text { Net incumbent } \\
\text { growth }\end{array}$ & World demand & & $\begin{array}{l}\text { Inter-industry interaction } \\
\text { Inter-regional interaction }\end{array}$ \\
\hline $\begin{array}{l}\text { Maggioni, 2002, } \\
2004\end{array}$ & $\begin{array}{l}\text { Cluster size (LQ) } \\
\text { New entry } \\
\text { Net incumbent } \\
\text { growth }\end{array}$ & & & $\begin{array}{l}\text { Inter-industry interaction } \\
\text { Inter-regional interaction }\end{array}$ \\
\hline $\begin{array}{l}\text { Menzel \& Fornahl, } \\
\text { 2007, } 2009\end{array}$ & $\begin{array}{l}\text { Number of } \\
\text { employment }\end{array}$ & & $\begin{array}{l}\text { Number of actors } \\
\text { Number of } \\
\text { organization }\end{array}$ & $\begin{array}{l}\text { Networking \& value chain } \\
\text { Exploitation of synergy } \\
\text { Perception of cluster } \\
\text { Capacity for collective } \\
\text { action } \\
\text { Knowledge, competencies } \\
\text { \& organization forms }\end{array}$ \\
\hline This research, 2012 & $\begin{array}{l}\text { Concentration of } \\
\text { industry } \\
\text { Index LQ }\end{array}$ & $\begin{array}{l}\text { Market } \\
\text { accessibility }\end{array}$ & $\begin{array}{l}\text { Completeness of } \\
\text { Actor: } \\
\text { Type of actor in } \\
\text { horizontal linkage } \\
\text { Type of actor in } \\
\text { vertical linkage }\end{array}$ & $\begin{array}{l}\text { Collaboration of } \\
\text { Stakeholders } \\
\text { Nature of collaboration } \\
\text { Mechanism of } \\
\text { collaboration } \\
\text { Strategic of collaboration } \\
\text { Type of collaboration } \\
\text { Condition of collaboration } \\
\text { Condition of institution } \\
\text { collaboration }\end{array}$ \\
\hline
\end{tabular}

Table 2. State of the art the assessment dimensions to identify phase of industrial cluster life cycle

According to Ulhaque (1995), Kotler, Wong, Saunders \& Armstrong (2005), Porter and Schwab (2008), and Schwab (2010), the dimension of market accessibility introduced above can also be used to determine industrial clusters growth. Demand for the cluster product can provide a measurement of the cluster growth (Porter, 
1985, 1990). Nadvi and Barrientos (2004) stated that global buyers can help the local cluster access the global market through external relations. Increased assets, capabilities, and market accessibility are the key factors to improving the industrial cluster's competitiveness, which can be measured by the cluster's ability to gain access to global markets (Porter 1990; Bergman, 2007). Competitiveness will thus stimulate the growth of the industrial cluster (Porter, 1990; Bergman, 2007). Therefore, we use market accessibility to assess cluster growth, because it explains the influence of marketing areas on that growth.

The definition of industrial cluster by Porter (1990) contains the essential elements of an industrial cluster. First, the cluster involves not only firms, but also of a specific supporting institutional. Second, only certain firms and institutions in a specific area are affiliated with the cluster, so there is an outer boundary of the cluster. Third, the firms and institutions are interconnected. These connections refer to market exchange process of good and services, cooperation which requires a mutual trust and technological proximity (Menzel \& Fornahl, 2006). Based on this definition, completeness of actors i.e. type of actor is determinant factor to identify phase of industrial cluster life cycle (Maggioni, 2002, 2004; Andersson et al., 2004; Menzel \& Fornahl, 2007, 2009; Maggioni \& Riggi, 2008). It can also represent a group of firms in the same or similar industries that are related to each other by vertical and horizontal linkages (Kotler, Jatusripitak \& Maesincee, 1997). Thus, the completeness of actors i.e. kinds of actor in these vertical and horizontal linkages is one dimension that can be used to identify phase of cluster life cycle.

According to Lyon and Atherton (2000), regardless of the differences in structure, size, or sector, three basic concerns characterize industrial clusters, namely commonality, concentration, and connectivity. According to Porter (1990), Kotler et al. (1997), and Bititci, Martinez, Albores \& Parung (2004), the characteristics of an industrial cluster interconnect the company with other stakeholders. This collaboration triggers the synergies and benefits of collocation, so industrial cluster will not be formed without it (Porter, 1990; Schmitz, 1995; Raco, 1999; Lyon \& Atherton, 2000; Lechner \& Dowling, 2003; Coughlan et al., 2003; Segil, 2004; JICA, 2004; Cohen \& Roussel, 2005; Brown et al., 2007; Niu, Miles \& Lee, 2008; Parung \& Bititci, 2008). Thus, the collaboration of stakeholders is one of the main dimensions that can be used to identify phase of cluster life cycle.

Table 3 shows the developing of assessment component involves dimensions, elements, and criteria. The elements are generated from dimensions. The criteria are generated from elements and then used to characterize each phases. 
Characterization of each phase is used to differentiate the condition of the industrial cluster. Determination and validation of the dimensions, elements, and criteria of the cluster phases are conducted using the Delphi Method.

\begin{tabular}{|c|c|c|c|}
\hline No. & Dimensions & Element & Criteria \\
\hline \multirow{16}{*}{1} & \multirow{16}{*}{$\begin{array}{l}\text { Completeness of } \\
\text { actors }\end{array}$} & \multirow{10}{*}{$\begin{array}{l}\text { Type of actor in horizontal } \\
\text { linkage }\end{array}$} & Focal company \\
\hline & & & Competitor \\
\hline & & & Government \\
\hline & & & Association \\
\hline & & & Institution of collaboration \\
\hline & & & Advisory or consultancy service \\
\hline & & & University \\
\hline & & & Financial institutions \\
\hline & & & $\begin{array}{l}\text { Training institution of technical } \\
\text { production }\end{array}$ \\
\hline & & & Research institution \\
\hline & & \multirow{6}{*}{$\begin{array}{l}\text { Type of actor in vertical } \\
\text { linkage }\end{array}$} & Focal company \\
\hline & & & Consumer \\
\hline & & & Supplier of raw material \\
\hline & & & Supplier of supporting material \\
\hline & & & Supplier of machinery and equipment \\
\hline & & & Supporting industry \\
\hline 2 & $\begin{array}{l}\text { Concentration of } \\
\text { industry }\end{array}$ & Location quotient (LQ) & Index LQ \\
\hline \multirow{24}{*}{3} & \multirow{24}{*}{$\begin{array}{l}\text { Collaboration of } \\
\text { stakeholders }\end{array}$} & \multirow{2}{*}{ Nature of collaboration } & Mechanistic \\
\hline & & & Organic \\
\hline & & \multirow{6}{*}{ Mechanism of collaboration } & Distribution and market sharing \\
\hline & & & Subcontract \\
\hline & & & Knowledge sharing \\
\hline & & & Information and technology sharing \\
\hline & & & $R \& D$ \\
\hline & & & License and private label \\
\hline & & \multirow{3}{*}{ Strategies of collaboration } & Operational \\
\hline & & & Tactical \\
\hline & & & Strategic \\
\hline & & \multirow{4}{*}{ Type of collaboration } & Transactional \\
\hline & & & Cooperative \\
\hline & & & Coordinative \\
\hline & & & Synchronized \\
\hline & & \multirow{5}{*}{ Condition of collaboration } & Communication \\
\hline & & & Trust \\
\hline & & & Commitment \\
\hline & & & Coordination \\
\hline & & & Conflict resolution \\
\hline & & \multirow{4}{*}{$\begin{array}{l}\text { Condition of institutional } \\
\text { collaboration }\end{array}$} & No institution \\
\hline & & & Passive \\
\hline & & & Active \\
\hline & & & Dynamic \\
\hline \multirow{3}{*}{4} & \multirow{3}{*}{$\begin{array}{l}\text { Market } \\
\text { accessibility }\end{array}$} & \multirow{3}{*}{ Marketing area } & Local \\
\hline & & & National \\
\hline & & & International \\
\hline
\end{tabular}

Table 3. Assessment criteria to identify phases of industrial cluster life cycle

\section{Identification phases of cluster life cycle}

\subsection{A conceptual model to identify phases of industrial cluster life cycle}

In this paper, a conceptual model developed consists of determination the phases of cluster life cycle, identification of assessment components, and design typology 
of cluster life cycle, as in Figure 1 . The phases of cluster life cycle i.e. agglomeration, emerging, developing, and mature that refers to Andersson et al. (2004), as in section 4.1. Identification of assessment components involves determination of dimensions, elements, and criteria as described in section 4.2. Typology of cluster life cycle is characteristic of each phase of cluster life cycle as explained in section 4.3 and 4.4 .

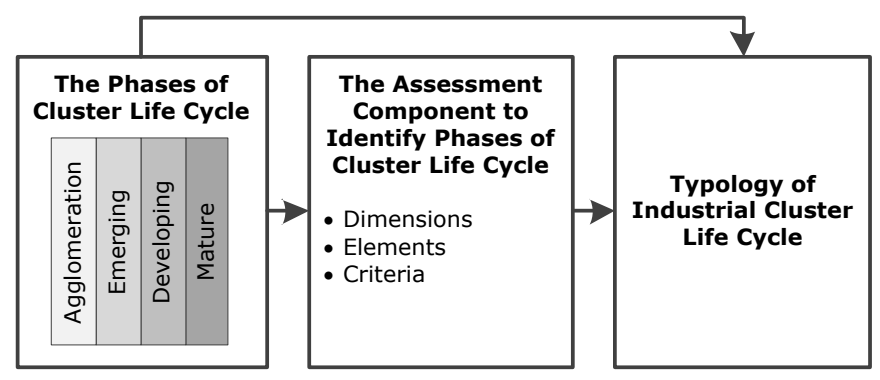

Figure 1. A conceptual model to identify phases of industrial cluster life cycle

\subsection{The framework of assessment to identify phases of cluster life cycle}

Figure 2 present the framework of assessment to identify phases of industrial cluster life cycle. There is two main entities i.e. industrial cluster and the government. Within the government, there is two main activities i.e. assessment of industrial cluster phase and policy intervention. An industrial cluster evolve through their life cycle, so for formulation appropriate policy intervention, the government should conduct assessment to identify phase of industrial cluster life cycle.

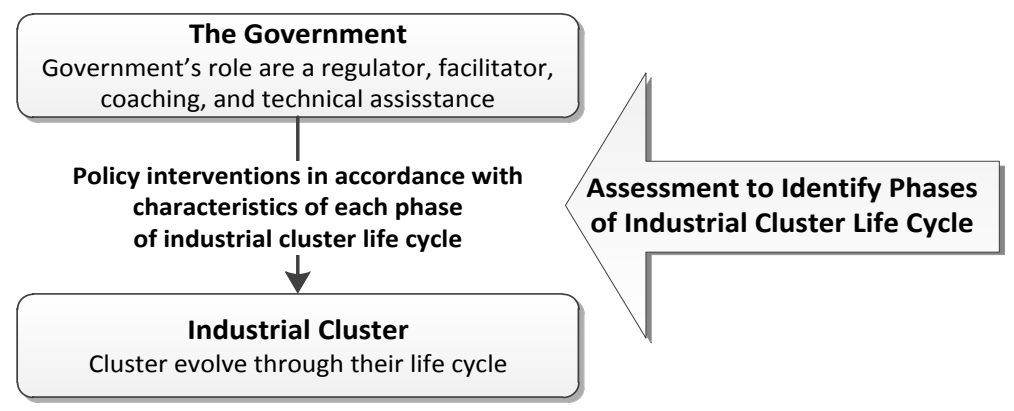

Figure 2. The framework of assessment to identify phase of industrial cluster life cycle

\section{Research methodology}

The steps of development of a conceptual assessment model to identify phases of cluster life cycle involve determination phases, identification assessment components and design typology of cluster life cycle, as in Figure 3. Delphi Method was used in each step. Refers to above explanation, there is limitation research 
about assessment conceptual model to identify phases of industrial cluster life cycle. Especially in Indonesia, there is no research about it and the clusters have differences characteristics. Thus, we combined deductive and inductive approach to develop a conceptual assessment model i.e. literature review and experts' opinion by Delphi Method. Experts' opinion is also as a construct validation of the results of literature studies that have been conducted.

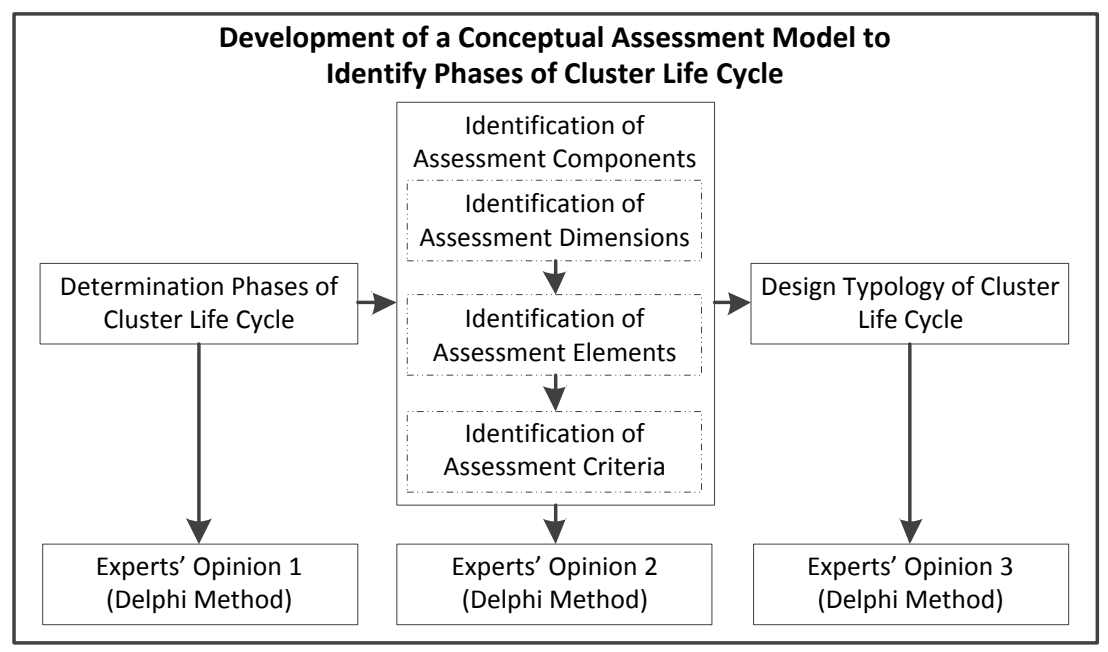

Figure 3. Research methodology to develop a conceptual assessment model

\subsection{Determination phases of cluster life cycle}

In this step, we determined phases of cluster life cycle that referred to Andersson et al (2004), because this definition more comprehensive to describe the cluster life cycle. In this research, we did not included transformation phase, because this phase has different product with previous phases. We used Delphi method to validate this problem. The determinant factor to distinguish this phase is the difference product that will affect differentiation of actors, technology, and markets of these clusters.

\subsection{Identification of assessment components}

Delphi method also was used to identify assessment components involve dimensions, elements, and criteria. In this step, we used mixed approaches to identify assessments components i.e. deductive (literature review) and inductive (Delphi method) due to limited literature in this field. These results are presented in section 5.2 . 


\subsection{Design typology of cluster life cycle}

The last step, we design typology of cluster life cycle. The typology is characteristics of each phase of cluster life cycle that was designed base on assessment criteria. The typology of each phase is ideal condition of each phase of cluster life cycle, and then, it will be used to define threshold value. Because of the limitation of literatures or researches in this field, we used Delphi method to design the typology of cluster life cycle. These results are presented in section 5 .

\subsection{The Delphi Methods}

\section{Applicability of the method for the research question}

This paper presents the findings from a Delphi study where experts were asked to contribute their opinions related to industrial cluster life cycle. The Delphi Method was used to develop the model. The objective of this method is to achieve the most reliable consensus within a group of experts. The method structures group communication so that individuals and the group as a whole can deal with a complex problem (Linstone \& Turoff, 1975; Okoli \& Pawlowski, 2004). The Delphi Method includes the iteration of three activities:

- Collect the opinion of an expert group, generally using a survey

- Synthesize and statistically recapitulate these opinions

- Provide feedback to the participants and see if any revision is required

Delphi Method is a structured communication technique, originally developed as a systematic, interactive forecasting method which relies on a panel of experts (Linstone \& Turoff, 1975). This method defines consensus as 'opinion stability' or the collective agreement among members of a group. This is accomplished using iterative rounds, i.e. sequential questionnaires interspersed with controlled feedback and the interpretation of experts' opinion. It provides an enabling mechanism for organizing conflicting values and experiences, and it facilitates the incorporation of multiple opinions into consensus. This method was applied in many fields to conduct consensus, for example, forecasting or issue identification/ prioritization, concept or framework development, and as basis development need assessment.

This study aims to develop the assessment conceptual model to identify phases of industrial cluster life cycle in Indonesia. Based on the literature review, there are a 
few researches in this field. The researches in the field of cluster life cycle usually explore about key success factors that influence the growth of cluster (in early phase) or how industrial cluster try to survive so that is not decline (in maturation phase). Especially in Indonesia, there has been no research conducted to identify phases of each industrial cluster at their life cycle. For solving this problem requires expert opinion to justify the issue both theoretically and empirically. The Delphi study allows expert opinion to be identified and also provides opportunities for structured feedback among experts. This method provides chance for participants to express their opinions without being influenced by another. Therefore, the Delphi Method is seen as a good choice to solve the problem. Thus, we used Delphi Method to define phase, identify assessment components, and design typology of cluster life cycle cause the limitations of studies and literatures in the field of cluster life cycle.

\section{Selection of experts}

The key point to validate the Delphi Method is how to select experts in order to identify the kind of knowledge. An expert is a professionally or scientifically qualified individual who is approved in the field of study. Experts were selected based on research experience and publications in the industrial cluster development area or the activity of their institution. The selection of respondents used the expert judgment sampling based on expertise.

Theoretically, the Delphi Method does not clearly presuppose the number of participants that involved. It is generally ruled by the number of participants needed to establish a representative combining of judgments and by the information processing capabilities of the design and monitoring team (Delbecq, Ven van de $\&$ Gustafson, 1975). The minimum number of participant to confirm a good performance depends on the study design. Hodgetts (1977) directed that at least eight panelists are required, but he did not provide justification for this minimum number. A panel consisting of about 10 experts is probably ideal, but more than 10 may be used if desired. De Loe (1995) suggests ten to fifty as an optimal number of participants in a Delphi survey to produce valid results. Selection participants should not only representative by stakeholders or individuals from a single institution, interest group, or geographical region.

The numbers of participant are eight experts and they come from the variety institutions that play a role in the industrial cluster development, i.e. local and central government, university, and NGO's. They were selected in accordance with their expertise in this research area. Therefore, these experts were considered to 
represent the other experts in this field. They have capability to solve the problem i.e. determination of assessment components and typology of industrial cluster life cycle. The other reason is limitation of experts who are knowledgeable and competent about cluster life cycle in Indonesia.

So, to overcome the limitation of experts' number, we strictly selected the experts that participate in the Delphi Method. The participants are representatives' stakeholders in cluster development and they have experience and expertise in this field. Thus, they should represent a diversity of competence and knowledge about industrial cluster growth, but priority should be given to selecting participants who are knowledgeable about characteristics of each phase of cluster life cycle.

The advantages of Delphi Methods are as follows:

- First, using the Delphi Method ignore the name of participant, so it prevents a great influence of one participants to another

- Second, there is possibility to cover a geographic area that is more narrow and heterogeneous of large groups that can participate on this process

- $\quad$ Third, there is discrete steps

- Fourth, each respondent has sufficient time

- Fifth, this method can avoid social and psychology pressures

- Sixth, there is direct attention to the problem

- Seventh, this method is in compliance with framework.

- Eighth, this method requires proper documentations of Delphi mechanism. It is necessary to ensure the validity and reliability of Delphi results.

The weaknesses of Delphi Method are as follows:

- First, this method requires a long time, according to some studies, the completion time of Delphi process is at least about 6 months

- Second, this method did not allowed for the possibility of direct verbal communication through individual meetings

- Third, respondents may misunderstand about the questionnaire or do not have the communication skills in written form 
- Fourth, the Delphi concept is experts. The experts may be present their opinion that cannot be scientifically defensible

- Fifth, the systematics Delphi inhibits exploration of thought because it does not allow dissent

- Sixth, this method did not allow for the prospectively contribution associated with the problem

- Seventh, this method assumes that can be a substitute for all human communication in various situations.

So, to overcome this weakness, Thangaritinam and Redman (2005) suggest confirming the findings with the other studies, clarifying mechanism process Delphi i.e. how select experts, procedure data collected, identifying consensus level, explaining the methods used for dissemination and implementation, etc.

The Delphi Method is based on the assumption that group judgments are more valid than individual judgments. The other assumptions are as follows:

- First, Delphi Method refers to experts' capability that used their knowledge and experience to solve the problem

- Second, there is problem complexity

- Third, focus groups discussion may not be implemented

- Fourth, the experts should represent diverse backgrounds with respect to experience or expertise

- Fifth, it is not allow for differences of opinion among participants.

Refers the above explanation, Delphi Method is systematically prevents exploration of thought because it does not allow dissent. These implications are the possibility of generating artificial consensus, avoiding extreme positions, and how disagreement could discourage dissenters. This is leading the failure of Delphi Method. For solving this problem, the researchers must strictly select the experts that participate in the Delphi Method and more attention to the diversity and representativeness of participants.

In this research, four different sets of experts were selected: central and local government policy makers, academic researchers, NGOs, and representatives of 
entrepreneurs. The intention was to achieve a wide range of interest groups and their respective opinions included in the research. The number of respondents was thirteen, with one each from the National Development Planning Board, Agency for Regional Development Central Java Province, Agency for the Assessment and Application of Technology, Agency of Industry Central Java Province, two each from the Ministry of Industry of the Republic of Indonesia, representatives of entrepreneurs (Chamber of Commerce, businessman), NGOs, three people from Universities (one an executive on the board of the Chamber of Commerce). In the first round, five respondents did not return the questionnaire. These were one person each from the Ministry of Industry, university, Chamber of Commerce, and two business people. In the second round, the number of respondents was the eight who had returned questionnaires in the first round.

\section{Number of polls and content of three polls}

According to Linstone and Turoff (1975), a Delphi study is supposed to continue until no further insights are gained, for example by receiving stable feedback as in the previous poll. In practice, it seems unlikely to have more than three polls in such a study. The content and outcome of the single rounds will be outlined in more detail below. Overall, the objective was to follow an ideal process of brainstorming, consolidation, and evaluation. In this research, the Delphi process was implemented in three rounds. Table 4 show the three steps used in this research.

\begin{tabular}{|l|l|l|l|}
\cline { 2 - 4 } \multicolumn{1}{c|}{} & $1^{\text {st }}$ round & $2^{\text {nd }}$ round & $3^{\text {rd }}$ round \\
\hline Definition of growth phases & A draft & Verification & - \\
\hline Assessment component taxonomy & A draft & Verification & Verification \\
\hline Characteristic of industrial cluster growth phases & A draft & Verification & Verification \\
\hline $\begin{array}{l}\text { Assessment model of industrial cluster growth } \\
\text { phases }\end{array}$ & - & - & Direct the model \\
\hline
\end{tabular}

Table 4. The steps of Delphi Method in this research

As the first step, a literature review on industrial clusters life cycle, including definition, assessment components, and characteristics of each phase and the assessment instrument to identify phases of industrial cluster life cycle was done. This activity reduced the iterations of the Delphi Method. The result of the literature review was set out in the next section.

\subsection{Data collection and response rate}

The data was collected between July 2009 and August 2010. The Delphi process mechanism can be explained as follows. Delphi questionnaires were delivered directly to each of the expert respondents, who could ask questions about the 
research contents and how to fill in the questionnaires. It took quite a long time to get responses and feedback from some respondents, due to their occupations. There were eight responses to each poll, resulting in an average response rate of about $87 \%$ (Table 5).

\begin{tabular}{|l|r|r|r|r|r|}
\hline Round & \multicolumn{1}{|l|}{ Policy maker } & \multicolumn{1}{l|}{ Academic } & \multicolumn{1}{l|}{ NGOs } & Entrepreneur & Response rate \\
\hline $1^{\text {st }}$ round & 6 & 3 & 1 & 3 & $62 \%$ \\
\hline $2^{\text {nd }}$ round & 5 & 2 & 1 & - & $100 \%$ \\
\hline $3^{\text {rd }}$ round & 5 & 2 & 1 & - & $100 \%$ \\
\hline
\end{tabular}

Table 5. Response Rate across the Participant Groups and Rounds

\subsection{Data analysis}

The eight feedbacks obtained in the first round were collected and then assessed for similarities. Calculation of the number of respondents or experts that choice the item can be calculated by the equation 1 ,

$$
X=\sum_{i=1}^{n} x_{i}
$$

The variance of respondents' choice can be calculated by the equation 2,

$$
S^{2}=\frac{\sum_{i=1}^{n}\left(x_{i}^{2}-\left(x_{i}\right)^{2}\right)}{n-1}
$$

If the variance of respondents' choice is less than or equal to 0.2 , it means that there is a homogeneity of respondents' opinion.

The results are as follows. At the first round, the respondents were asked about the definition of industrial cluster life cycle to use. The cluster life cycle relate to Andersson et al., (2004), but with the transformation phase eliminated. The consensus was that the transformation phase is a new group because the cluster product is different. It will have an impact seen in differences in production processes, technologies, markets, and changes of actors involved in the growth of industrial clusters. Moreover, in this step we proposed a draft about the assessment components taxonomy to identify phases of industrial cluster life cycle and characteristics of these phases based on the assessment criteria. The first round results were collected, analyzed, and synthesized into an updated life cycle model. To synthesize the results of the first step, we organized opinions that were basically the same but expressed in a different way. If the content was the same but just differed in expression, we combined the responses, and edited them to get a summary response, reflecting this content. If there were significant variations, then we combined the responses but stressed where the differences occurred so that in 
the second round the experts would be able to respond directly to where consensus was not achieved. There were several respondent opinions that added to this research by complementing our assessment components.

At the second round, the experts were provided with feedback to validate the results from the first round, and to resolve the differences stressed in the first round. The results were analyzed and synthesized to obtain a consensus model that was sent to be reviewed again in the third round. In this step, respondents verified the definition of cluster life cycle, the assessment component taxonomy, and the characteristics of each phase that called typology of industrial cluster life cycle.

\begin{tabular}{|c|c|c|c|c|c|c|c|c|c|c|}
\hline \multirow{2}{*}{ Dimension } & \multirow{2}{*}{ Element } & \multirow{2}{*}{ Criteria } & \multicolumn{2}{|c|}{ Agglomeration } & \multicolumn{2}{|c|}{ Emerging } & \multicolumn{2}{|c|}{ Developing } & \multicolumn{2}{|c|}{ Maturation } \\
\hline & & & Tot & Var & Tot & Var & Tot & Var & Tot & Var \\
\hline \multirow{16}{*}{$\begin{array}{l}\text { Completeness } \\
\text { of actors }\end{array}$} & \multirow{10}{*}{$\begin{array}{l}\text { Type of actor } \\
\text { in horizontal } \\
\text { linkage }\end{array}$} & Focal company & 8 & 0 & 8 & 0 & 8 & 0 & 8 & 0 \\
\hline & & Competitor & 7 & 0.1 & 7 & 0.1 & 7 & 0.1 & 8 & 0 \\
\hline & & Government & & & 8 & 0 & 8 & 0 & 8 & 0 \\
\hline & & Association & & & 7 & 0.1 & 7 & 0.1 & 7 & 0.1 \\
\hline & & Institution of collaboration & & & & & 6 & 0.2 & 8 & 0 \\
\hline & & Advisory or consultancy service & & & & & 7 & 0.1 & 8 & 0 \\
\hline & & University & & & & & 7 & 0.1 & 8 & 0 \\
\hline & & Financial institutions & & & & & 8 & 0 & 8 & 0 \\
\hline & & $\begin{array}{l}\text { Training institution of technical } \\
\text { production }\end{array}$ & & & & & 6 & 0.2 & 8 & 0 \\
\hline & & Research institution & & & & & & & 8 & 0 \\
\hline & \multirow{6}{*}{$\begin{array}{l}\text { Type of actor } \\
\text { in vertical } \\
\text { linkage }\end{array}$} & Focal company & 8 & 0 & 8 & 0 & 8 & 0 & 8 & 0 \\
\hline & & Consumer & 8 & 0 & 8 & 0 & 8 & 0 & 8 & 0 \\
\hline & & Supplier of raw material & 6 & 0.2 & 8 & 0 & 8 & 0 & 8 & 0 \\
\hline & & Supplier of supporting material & & & 6 & 0.2 & 8 & 0 & 8 & 0 \\
\hline & & $\begin{array}{l}\text { Supplier of machinery and } \\
\text { equipment }\end{array}$ & & & & & 7 & 0.1 & 8 & 0 \\
\hline & & Supporting industry & & & & & 6 & 0.2 & 8 & 0 \\
\hline \multirow{4}{*}{$\begin{array}{l}\text { Concentration } \\
\text { of industry }\end{array}$} & \multirow{4}{*}{$\begin{array}{l}\text { Location } \\
\text { quotient (LQ) }\end{array}$} & Index $\mathrm{LQ}<1$ & 7 & 0.1 & & & & & & \\
\hline & & Index LQ = 1 & & & 7 & 0.1 & & & & \\
\hline & & $1<$ index $\mathrm{LQ}<1.3$ & & & & & 7 & 0.1 & & \\
\hline & & Index LQ $\geq 1.3$ & & & & & & & 6 & 0.2 \\
\hline \multirow{24}{*}{$\begin{array}{l}\text { Collaboration } \\
\text { of } \\
\text { stakeholders }\end{array}$} & \multirow{2}{*}{$\begin{array}{l}\text { Nature of } \\
\text { collaboration }\end{array}$} & Mechanistic & 7 & 0.1 & 7 & 0.1 & 7 & 0.1 & & \\
\hline & & Organic & & & & & 7 & 0.1 & 8 & 0 \\
\hline & \multirow{6}{*}{$\begin{array}{l}\text { Mechanism of } \\
\text { collaboration }\end{array}$} & $\begin{array}{l}\text { Distribution and market } \\
\text { sharing }\end{array}$ & 8 & 0 & 8 & 0 & 8 & 0 & 8 & 0 \\
\hline & & Subcontract & 7 & 0.1 & 7 & 0.1 & 8 & 0 & 8 & 0 \\
\hline & & Knowledge sharing & & & 7 & 0.1 & 7 & 0.1 & 8 & 0 \\
\hline & & $\begin{array}{l}\text { Information and technology } \\
\text { sharing }\end{array}$ & & & & & 8 & 0 & 8 & 0 \\
\hline & & $R \& D$ & & & & & & & 7 & 0.1 \\
\hline & & License and private label & & & & & & & 7 & 0.1 \\
\hline & \multirow{3}{*}{$\begin{array}{l}\text { Strategies of } \\
\text { collaboration }\end{array}$} & Operational & 8 & 0 & 8 & 0 & 8 & 0 & 6 & 0.2 \\
\hline & & Tactical & & & 7 & 0.1 & 8 & 0 & 7 & 0.1 \\
\hline & & Strategic & & & & & & & 8 & 0 \\
\hline & \multirow{4}{*}{$\begin{array}{l}\text { Type of } \\
\text { collaboration }\end{array}$} & Transactional & 7 & 0.1 & 8 & 0 & 6 & 0.2 & 7 & 0.1 \\
\hline & & Cooperative & & & 6 & 0.2 & 8 & 0 & 8 & 0 \\
\hline & & Coordinative & & & & & 6 & 0.2 & 8 & 0 \\
\hline & & Synchronized & & & & & & & 6 & 0.2 \\
\hline & \multirow{5}{*}{$\begin{array}{l}\text { Condition of } \\
\text { collaboration }\end{array}$} & Communication & 7 & 0.1 & 8 & 0 & 8 & 0 & 8 & 0 \\
\hline & & Trust & & & 6 & 0.2 & 7 & 0.1 & 8 & 0 \\
\hline & & Commitment & & & & & 8 & 0 & 8 & 0 \\
\hline & & Coordination & & & & & 7 & 0.1 & 8 & 0 \\
\hline & & Conflict resolution & & & & & & & 8 & 0 \\
\hline & \multirow{4}{*}{$\begin{array}{l}\text { Condition of } \\
\text { institutional } \\
\text { collaboration }\end{array}$} & No institution & 8 & 0 & & & & & & \\
\hline & & Passive & & & 8 & 0 & & & & \\
\hline & & Active & & & & & 8 & 0 & & \\
\hline & & Dynamic & & & & & & & 8 & 0 \\
\hline & & Local & 7 & 0.1 & 7 & 0.1 & 7 & 0.1 & 6 & 0.2 \\
\hline Market & Marketing & National & & & & & 6 & 0.2 & 7 & 0.1 \\
\hline & & International & & & & & & & 6 & 0.2 \\
\hline
\end{tabular}

Table 6. Data Collection and Variance Calculation the Delphi Results in Round 3

At the third round, no additional information was sought from the experts, but rather we clarified the model and reached consensus. Consensus was proven by 
variance calculation of each criterion equal to or less than 0.2. The calculation result was indicated for each item agreed upon by 6 out of 8 respondents and variation equal to or less than 0.2. Based on the general agreement, the consensus can be taken if the variation of the respondents choices is less than or equal to $20 \%$. This indicates the homogenous of respondents' understanding about the problem that was discussed. It means the respondents have uniform knowledge about the problem.

Table 6 describes the data collection and variance calculation from the Delphi results for characterization of each phase of industrial cluster life cycle. It presents characteristics of each phase i.e. agglomeration, emerging, developing, and maturation that describes based on their assessment criteria. This is representing the maximum condition of each phase, which is the basis to determine the threshold value. For example, in agglomeration phase, the completeness of actors dimension include focal company that was approved by eight participants with variance value is 0 , competitor that was approved by seven participants with variance value is 0.1 , consumer that was approved by eight participants with variance value is 0 , and supplier of raw material that was approved by six participants with variance value is 0.2 , it means that the fourth item agreed upon the respondent as criteria for the element of type of actor in horizontal linkages. The same explanation applies to the next dimensions and elements.

\section{The results}

\subsection{Determination the phases of cluster life cycle}

We herein use four phase of cluster life cycle, namely agglomeration, emerging, developing, and mature that refers to Andersson et al. (2004). This definition is the most comprehensive for describing the cluster life cycle. Agglomeration is the initial phase when focal companies in the related product group begin to form. Emerging occurs when the agglomeration is able to attract other stakeholders to join the cluster that marked by begin of collaboration. Developing is marked by collaboration between stakeholders encourages the growth of industrial clusters and increases products' market accessibility. Mature is the real clusters that is characterized by critical mass. The last phase is decline or transformation.

In this study, transformation is not used because in this phase the cluster will form a new cluster. This is characterized by differences in products as a result of specialization in workers' competences or product differentiation from that of the previous cluster. This leads to changes in markets, production processes, and 
technology because of differences in actors and supporting institutions. A transformation cluster is not always in the mature phase; it can be in any one of their life cycle. Furthermore, the decline phase was not investigated because the purpose of this research is to accelerate the growth of industrial clusters. In addition, an industrial cluster can come into the decline phase before the mature phase if it is unable to maintain and improve the determinants of industrial cluster growth.

\begin{tabular}{|c|c|c|c|c|}
\hline Dimension & $\begin{array}{l}\text { Operational } \\
\text { Definitions }\end{array}$ & Element & Operational Definitions & References \\
\hline \multirow{2}{*}{$\begin{array}{l}\text { Completeness of } \\
\text { actors, a } \\
\text { dimension to } \\
\text { identify the type } \\
\text { of actor who joins } \\
\text { the cluster }\end{array}$} & \multirow{2}{*}{$\begin{array}{l}\text { Types of } \\
\text { entities (actors } \\
\text { / stakeholders) } \\
\text { who join the } \\
\text { industrial } \\
\text { cluster }\end{array}$} & $\begin{array}{l}\text { Type of } \\
\text { actors in } \\
\text { horizontal } \\
\text { linkages }\end{array}$ & $\begin{array}{l}\text { Type of actors in the linkage } \\
\text { between the core industry } \\
\text { with competitors, and other } \\
\text { institutions }\end{array}$ & \multirow{2}{*}{$\begin{array}{l}\text { Porter, 1990; } \\
\text { Kotler et al., } \\
\text { 1997; Maggioni, } \\
\text { 2002, 2004; } \\
\text { Andersson et } \\
\text { al., 2004; } \\
\text { Menzel \& } \\
\text { Fornahl, 2007, } \\
\text { 2009; Maggioni } \\
\text { \& Riggi, 2008 }\end{array}$} \\
\hline & & $\begin{array}{l}\text { Type of } \\
\text { actors in } \\
\text { vertical } \\
\text { linkages }\end{array}$ & $\begin{array}{l}\text { Type of actors in the linkage } \\
\text { between the core industry } \\
\text { with upstream and } \\
\text { downstream industries along } \\
\text { the value chain of production }\end{array}$ & \\
\hline $\begin{array}{l}\text { Concentration of } \\
\text { industry, } \\
\text { a dimension to } \\
\text { measure the } \\
\text { number of } \\
\text { companies that } \\
\text { join the cluster }\end{array}$ & $\begin{array}{l}\text { Relative } \\
\text { concentration of } \\
\text { specific } \\
\text { industries in the } \\
\text { region } \\
\text { compared to } \\
\text { national } \\
\text { average }\end{array}$ & $\begin{array}{l}\text { Location } \\
\text { Quotient }\end{array}$ & $\begin{array}{l}\text { Relative concentration of } \\
\text { employment in a specific } \\
\text { industries sector in the } \\
\text { region compared to national } \\
\text { average }\end{array}$ & $\begin{array}{l}\text { Maggioni, 2002, } \\
\text { 2004; Mayer, } \\
\text { 2003; Cortright, } \\
\text { 2006; Maggioni } \\
\text { \& Riggi, } 2008\end{array}$ \\
\hline \multirow{6}{*}{$\begin{array}{l}\text { Collaboration of } \\
\text { stakeholders, a } \\
\text { dimension to } \\
\text { identify the level } \\
\text { of joint action and } \\
\text { collective } \\
\text { efficiency between } \\
\text { firms in the } \\
\text { cluster }\end{array}$} & \multirow{6}{*}{$\begin{array}{l}\text { Cooperation } \\
\text { among actors / } \\
\text { stakeholders in } \\
\text { industrial } \\
\text { clusters }\end{array}$} & $\begin{array}{l}\text { Nature of } \\
\text { collaboration }\end{array}$ & $\begin{array}{l}\text { Model of organizational } \\
\text { relationships that forms the } \\
\text { cooperation/ collaboration }\end{array}$ & $\begin{array}{l}\text { Gibson, } \\
\text { Ivancevich \& } \\
\text { Donelly, } 2003\end{array}$ \\
\hline & & $\begin{array}{l}\text { Mechanisms } \\
\text { of } \\
\text { collaboration }\end{array}$ & $\begin{array}{l}\text { The way cluster members } \\
\text { cooperate/collaborate with } \\
\text { each other }\end{array}$ & $\begin{array}{l}\text { Segil, 2004, Lin } \\
\text { Tung \& Huang, } \\
2006\end{array}$ \\
\hline & & $\begin{array}{l}\text { Strategies of } \\
\text { collaboration }\end{array}$ & $\begin{array}{l}\text { Level of interest in } \\
\text { conducting cooperation/ } \\
\text { collaboration }\end{array}$ & $\begin{array}{l}\text { Coughlan et al., } \\
2003\end{array}$ \\
\hline & & $\begin{array}{l}\text { Type of } \\
\text { collaboration }\end{array}$ & $\begin{array}{l}\text { Type of relationships that } \\
\text { underlies the } \\
\text { cooperation/collaboration }\end{array}$ & $\begin{array}{l}\text { Cohen \& } \\
\text { Roussel, } 2005\end{array}$ \\
\hline & & $\begin{array}{l}\text { Condition of } \\
\text { collaboration }\end{array}$ & $\begin{array}{l}\text { Level of conditions that can } \\
\text { strengthen the cooperation/ } \\
\text { collaboration }\end{array}$ & $\begin{array}{l}\text { Parung \& Bititci, } \\
2008\end{array}$ \\
\hline & & $\begin{array}{l}\text { Condition of } \\
\text { institutional } \\
\text { collaboration }\end{array}$ & $\begin{array}{l}\text { Condition of institution/ } \\
\text { organization which joins the } \\
\text { cluster }\end{array}$ & JICA, 2004 \\
\hline $\begin{array}{l}\text { Market } \\
\text { accessibility, a } \\
\text { dimension to } \\
\text { measure the } \\
\text { extent of } \\
\text { industrial clusters } \\
\text { able to penetrate } \\
\text { the market or the } \\
\text { product marketing } \\
\text { area of the cluster }\end{array}$ & $\begin{array}{l}\text { Product } \\
\text { marketing area } \\
\text { of industrial } \\
\text { cluster }\end{array}$ & $\begin{array}{l}\text { Marketing } \\
\text { area }\end{array}$ & $\begin{array}{l}\text { Broad range of marketing } \\
\text { area of industrial cluster's } \\
\text { products }\end{array}$ & $\begin{array}{l}\text { Porter, 1985, } \\
\text { 1990; Ulhaque, } \\
\text { 1995; Kotler et } \\
\text { al., 2005; Porter } \\
\text { \& Schwab, } \\
2008 ; \text { Schwab, } \\
2010\end{array}$ \\
\hline
\end{tabular}

Table 7. Operational definitions of dimensions and elements to identify phases of industrial cluster life cycle 


\subsection{Assessment component to identify phases of cluster life cycle}

Some researchers use the concentration of industry and market accessibility to assess industrial cluster growth. However, these dimensions cannot discriminate the phase of industrial cluster life cycle. Based on the industrial cluster definitions (Porter, 1990), we concluded that industrial clusters is formed by the completeness of actors i.e. type of actor who joins in cluster and the collaboration between stakeholders. Thus, we enhance the completeness of actors and collaboration of stakeholders as dimensions to identify phase of cluster life cycle. The proposed dimensions and elements to identify phases of industrial cluster life cycle are as in Table 7 (Handayani et al., 2009; Handayani et al., 2010). Table 7 also mentions the operational definition of dimensions and elements.

A model for assessment to identify phases of industrial cluster life cycle can be formulated in Equation (3),

$$
I C P=f(C I, M A, C A, C S)
$$

Where: $I C P=$ industrial cluster phases, $C I=$ concentration of industry, $\mathrm{MA}=$ market accessibility, $C A=$ completeness of actors, $C S=$ collaboration of stakeholders.

\subsection{Typology of industrial cluster life cycle}

The next step is to design typology of industrial cluster life cycle, which is developed by characterization of each phase of cluster life cycle. The goal is to determine the typology by describing the condition of each phase based on the assessment criteria. This is done with the same experts as in the previous steps, again using the Delphi Method. Table 8 shows the results.

The agglomeration phase is an initial phase when the companies join in a certain area. The main actors are the focal company, competitors, customers, suppliers of raw materials. Industrial concentration is low when the LQ index is less than 1 , indicating that growth is not occurring in the area. Collaboration has not been established yet. Therefore, there is no institution of collaboration. The product from the cluster only serves the needs of its local markets. In order to develop a cluster from the agglomeration phase, the stakeholders have to deliver coaching to the main actors as well as to attract new players to join the cluster. 


\begin{tabular}{|c|c|c|c|}
\hline Agglomeration & Emerging & Developing & Maturation \\
\hline \multicolumn{4}{|c|}{ Dimension of Completeness of Actor } \\
\hline \multicolumn{4}{|c|}{ Element of Type of Actor in Horizontal Linkage } \\
\hline $\begin{array}{l}\text { Focal company } \\
\text { Competitor }\end{array}$ & $\begin{array}{l}\text { Focal company } \\
\text { Competitor } \\
\text { Government } \\
\text { Association }\end{array}$ & $\begin{array}{l}\text { Focal company } \\
\text { Competitor } \\
\text { Government } \\
\text { Association } \\
\text { Institution of } \\
\text { collaboration } \\
\text { Advisory or consultancy } \\
\text { service } \\
\text { University } \\
\text { Financial institutions } \\
\text { Training institution of } \\
\text { technical production }\end{array}$ & $\begin{array}{l}\text { Focal company } \\
\text { Competitor } \\
\text { Government } \\
\text { Association } \\
\text { Institution of } \\
\text { collaboration } \\
\text { Advisory or consultancy } \\
\text { service } \\
\text { University } \\
\text { Financial institutions } \\
\text { Training institution of } \\
\text { technical production } \\
\text { Research institution }\end{array}$ \\
\hline \multicolumn{4}{|c|}{ Element of Type of Actor in Vertical Linkage } \\
\hline $\begin{array}{l}\text { Focal company } \\
\text { Consumer } \\
\text { Supplier of raw material }\end{array}$ & $\begin{array}{l}\text { Focal company } \\
\text { Consumer } \\
\text { Supplier of raw material } \\
\text { Supplier of supporting } \\
\text { material }\end{array}$ & $\begin{array}{l}\text { Focal company } \\
\text { Consumer } \\
\text { Supplier of raw material } \\
\text { Supplier of supporting } \\
\text { material } \\
\text { Supplier of machinery \& } \\
\text { equipment } \\
\text { Supporting industry }\end{array}$ & $\begin{array}{l}\text { Focal company } \\
\text { Consumer } \\
\text { Supplier of raw material } \\
\text { Supplier of supporting } \\
\text { material } \\
\text { Supplier of machinery \& } \\
\text { equipment } \\
\text { Supporting industry }\end{array}$ \\
\hline \multicolumn{4}{|c|}{ Dimension of Concentration of Industry } \\
\hline \multicolumn{4}{|c|}{ Element of Location Quotient } \\
\hline $\mathrm{LQ}<1$ & $\mathrm{LQ}=1$ & $1<\mathrm{LQ}<1,3$ & $\mathrm{LQ} \geq 1,3$ \\
\hline \multicolumn{4}{|c|}{ Dimension of Collaboration of Stakeholders } \\
\hline \multicolumn{4}{|c|}{ Element of Nature of Collaboration } \\
\hline Mechanistic & Mechanistic & Mechanistic and Organic & Organic \\
\hline \multicolumn{4}{|c|}{ Element of Mechanism of Collaboration } \\
\hline $\begin{array}{l}\text { Distribution \& market } \\
\text { sharing } \\
\text { Subcontract }\end{array}$ & $\begin{array}{l}\text { Distribution \& market } \\
\text { sharing } \\
\text { Subcontract } \\
\text { Knowledge sharing }\end{array}$ & $\begin{array}{l}\text { Distribution \& market } \\
\text { sharing } \\
\text { Subcontract } \\
\text { Knowledge sharing } \\
\text { Information \& } \\
\text { technology sharing }\end{array}$ & $\begin{array}{l}\text { Distribution \& market } \\
\text { sharing } \\
\text { Subcontract } \\
\text { Knowledge sharing } \\
\text { Information \& } \\
\text { technology sharing } \\
\text { R \& D } \\
\text { License \& private label }\end{array}$ \\
\hline \multicolumn{4}{|c|}{ Element of Strategies of Collaboration } \\
\hline Operational & $\begin{array}{l}\text { Operational } \\
\text { Tactical }\end{array}$ & $\begin{array}{l}\text { Operational } \\
\text { Tactical }\end{array}$ & $\begin{array}{l}\text { Operational } \\
\text { Tactical } \\
\text { Strategic }\end{array}$ \\
\hline \multicolumn{4}{|c|}{ Element of Type of Collaboration } \\
\hline Transactional & $\begin{array}{l}\text { Transactional } \\
\text { Cooperative }\end{array}$ & $\begin{array}{l}\text { Transactional } \\
\text { Cooperative } \\
\text { Coordinative }\end{array}$ & $\begin{array}{l}\text { Transactional } \\
\text { Cooperative } \\
\text { Coordinative } \\
\text { Synchronized } \\
\end{array}$ \\
\hline \multicolumn{4}{|c|}{ Element of Condition of Collaboration } \\
\hline Communication & $\begin{array}{l}\text { Communication } \\
\text { Trust }\end{array}$ & $\begin{array}{l}\text { Communication } \\
\text { Trust } \\
\text { Commitment } \\
\text { Coordination }\end{array}$ & $\begin{array}{l}\text { Communication } \\
\text { Trust } \\
\text { Commitment } \\
\text { Coordination } \\
\text { Conflict resolution }\end{array}$ \\
\hline \multicolumn{4}{|c|}{ Element of Condition of Institutional Collaboration } \\
\hline No institution & Passive & Active & Dynamic \\
\hline \multicolumn{4}{|c|}{ Dimension of Market Accessibility } \\
\hline \multicolumn{4}{|c|}{ Element of Marketing Area } \\
\hline Local & Local & $\begin{array}{l}\text { Local } \\
\text { National }\end{array}$ & $\begin{array}{l}\text { Local } \\
\text { National } \\
\text { International }\end{array}$ \\
\hline
\end{tabular}

Table 8. Typology of Industrial Cluster Life Cycle

The emerging phase is the beginning of collaboration. Three new actors join the cluster, namely the government, associations, and suppliers of supporting material. 
If the LQ index is equal to 1 , it means that the industry is beginning to grow in the area. Collaboration is characterized by the existence of institutions both formal and non-formal. In addition, there is communication and trust among the stakeholders as the basis to establish cooperation. In this phase, the focus of attention is the actors' coaching, increasing collaboration and cooperation with other stakeholders to accelerate the cluster's growth.

The developing phase is marked by a high growth gradient. Innovation is introduced. There are seven new actors who join the cluster. The LQ index ranges from 1 to 1.3 , which means that growth is taking place and product competitiveness is being promoted. Collaboration activity is increased by having a formal institution and awareness from all members of the importance of cooperation. The marketing areas for the cluster's product expand to local and national markets. In order to develop this phase, we must focus on increasing the collaboration and access to other institutions. Besides that, improved innovation skills are needed to accelerate the cluster's growth.

The maturation phase is the real cluster, marked by the critical mass of actors. The LQ index is equal to or greater than 1.3. This means that industrial growth is occurring in the area and that the product has strong competitiveness. The collaborations among the stakeholders reach a peak and focus on competency. Innovations are boosted by $R \& D$ and there is awareness of the importance of patents. The marketing area of the product cluster begins to penetrate the international market. The focus in this phase is to maintain existing conditions through innovation and collaboration with other clusters.

\section{Conclusion and future research}

This paper is part of our researches about development assessment model to identify phases of industrial cluster life cycle. The step of researches are define the phases of cluster life cycle, identify assessment components, design typology of cluster life cycle, design assessment instruments, and develop assessment model that are include determine the weight of dimensions and elements and formulate the model. This paper describes three steps of research i.e. define the phases of cluster life cycle, identify assessment components, and design typology of cluster life cycle. Research methodology that used in these step is Delphi Method. It was caused limitation of literature and experts in this field.

We describe the definition of industrial cluster life cycle, namely: 
- Agglomeration

- Emerging

- Developing

- Maturation

The proposed dimensions used to assess the phases of cluster life cycle are:

- Concentration of industry

- Market accessibility

- Completeness of actor

- Collaboration of stakeholders

Typology of cluster life cycle was design to define threshold value of each phase of cluster life cycle that described the characteristics of each phase based on the criteria.

The assessment of industrial cluster life cycle allows the government to determine the initial condition of each cluster. The proposed model is expected to be able to differentiate the phases of industrial cluster life cycle. Thus, the model could answer this problem in order to formulate appropriate policy interventions for cluster development.

In future research, refers to the results of this paper, we will develop assessment model to identify phases of industrial cluster life cycle, which are include determine the weight of dimensions and elements and formulate the model. For testing the model, we conduct empirical studies to validate the assessment model. As described above, there are no papers that develop model to identify phases of industrial cluster life cycle. We bridge this gap to develop assessment model.

\section{Acknowledgment}

This research was partially funded by the DGHE, Ministry of National Education, the Republic of Indonesia in Hibah Disertasi S3 Program (Contract No. 501/SP2H/PP /DP2M/VI/2010). This paper is dedicated to the late Prof. Dr. Ir. Alibasyah Siregar. 


\section{References}

Altena, P., \& Heijman, W. (2007). In search of cluster. Applied Studies in Agribusiness and Commerce, 1(1), 7-18. Hungary: Agroinform Publishing House.

Andersson, T., Serger, S.S., Sorvik, J., \& Hansson, E.W. (2004). The Cluster Policies Whitebook. Sweden: IKED.

Azis, K. A., Richardson, S., \& Azis, N. A. A. (2011). Cluster lifecycle: A Case study of the Glasgow-Edinburgh corridor. Proceeding of the International Conference on Management and Artificial Intelligence. IPEDR, 6. IACSIT Press, Bali, Indonesia.

Barkley, D. L., \& Henry, M. S. (1997). Rural industrial development: To cluster or not to cluster? Review of Agricultural Economics, 2, 308-325. http://dx.doi.org/10.2307/1349744

Bergman, E. M. (2007). Cluster life-cycles: An emerging synthesis. SRE-Discussion Papers. Institut für Regional und Umweltwirtschaft. Vienna: WU Vienna University of Economics and Business. http://dx.doi.org/10.1108/09600030410533574

Bianchi, P., Miller, L. M., \& Bertini, S. (1997). The Italian SME Experience and Possible Lessons for Emerging Countries. Bologna: Nomisma.

Bititci, U. S., Martinez, V., Albores, P., \& Parung, J. (2004). Creating and managing value in collaborative networks. International Journal of Physical Distribution \& Logistics Management, 34(3), 251-268.

Bresnahan, T., Gambardella, A., \& Saxenian, A. (2001). 'Old Economy' inputs for 'New Economy' outcomes: Cluster formation in the New Silicon Valleys. Industrial and Corporate Change, 10(4), 835-860. http://dx.doi.org/10.1093/icc/10.4.835

Brown, K., Burgess, J., Festing, M., Royer, S., Steffen, C., \& Waterhouse, J. (2007). Towards a new conceptualization of clusters. Proceedings of the Managing Our Intellectual and Social Capital, 21st ANZAM 2007 Conference, 1-13, Sidney, Australia.

Cohen, S., \& Roussel, J. (2005). Strategic supply chain management, the five disciplines for top performance. New York: McGraw-Hill.

Cortright, J. (2006). Making sense of clusters: Regional competitiveness and economic development. The Brookings Institution Metropolitan Policy Program. 
Coughlan, P., Coghlan, D., Lombard, F., Brennan, L., McNichols, T. \& Nolan, R. (2003). Managing collaborative relationships in a period of discontinuity. International Journal of Operations and Productions Management, 23(10), 12461259. http://dx.doi.org/10.1108/01443570310496652

Delbecq., A. L., Ven van de, A. H., \& Gustafson, D. H. (1975). Group techniques for program planning. A guide to nominal group and Delphi processes. Glenview, IL: Scott, Foresman and Company.

De Loe, R. C. (1995). Exploring complex policy questions using the policy Delphi: A multi-round, interactive survey method. Applied Geography, 15(1), 53-68. http://dx.doi.org/10.1016/0143-6228(95)91062-3

Feser, E. (2004). Industry clusters and economic development: A learning resource, community and economic development toolbox. In J. Cortright (Eds), Making sense of clusters: Regional competitiveness and economic development. The Brookings Institution Metropolitan Policy Program.

Gibson, L. J., Ivancevich, J. M., \& Donelly, J. H. (2003). Organization: Behavior, structure and process. (10 $10^{\text {th }}$ Ed.). Chicago: Irwin.

Handayani, N. U., Siregar, A., Diawati, L., \& Cakravastia, A. (2009). Conceptual framework to determine factors of development phases of industrial cluster in Indonesia. Proceeding of the 10th Asia Pacific Industrial Engineering \& Management Systems Conference (APIEMS 2009), Kitakyushu Conference Centre. Kitakyushu. Japan. December $14^{\text {th }}-16^{\text {th }}, 2009$.

Handayani, N.U., Diawati, L., Cakravastia, A., \& Nur Bahagia, S. (2010). Determinant Factors to classify the growth phases of industrial cluster in Indonesia. Proceeding of the International Conference on Management, Innovation and Technology (ICMIT 2010), Gumaya Hotel. Semarang. Indonesia. October 27th 2010.

Hodgetts, R. M. (1977). Applying the Delphi technique to management gaming. Simulation, 29(1), 209-212. http://dx.doi.org/10.1177/003754977702900103

JICA (2004). Studi penguatan kapasitas klaster UKM di Republik Indonesia.

Kotler, P., Jatusripitak, S., \& Maesincee, S. (1997). The marketing of nations, A strategic approach to building national wealth. New York: The Free Press. 
Kotler, P., Wong, V., Saunders, J., \& Armstrong, G. (2005). Principles of marketing. (4th European Ed.). Prentice Hall International/Pearson Education Limited.

Lechner, C., \& Dowling, M. (2003). Firms networks: External relationships as sources for the growth and competitiveness of entrepreneurial firms. Entrepreneurship \& Regional Development, 15, 1-26. http://dx.doi.org/10.1080/08985620210159220

Lin, C. H., Tung, C. M., \& Huang, C. T. (2006). Elucidating the industrial cluster effect from a system dynamics perspective. Technovation, 26, 473-482.

Linstone, H. A., \& Turoff, M. (1975). The Delphi Method: Techniques and applications. Online edition of the original published by Addison-Wesley, Reading, MA.

Lorenzen, M. (2005). Why do clusters change?, European Urban and Regional Studies, 12, 203-208. http://dx.doi.org/10.1177/0969776405059046

Lyon, F., \& Atherton, A. (2000). A business view of clustering: Lessons for cluster development policies. Foundation for SME Development. University of Durham. Durham. In D. Beeton, L. Shearer, M. Houghton, \& F. Dodd (Eds.), Investigating models of clustering. Prepared for Sedge field Borough Council. TBR Economics.

Mayer, H. (2003). A Guide for analyzing industry clusters in the Portland-Vancouver metropolitan region. Institute of Portland Metropolitan Studies -New Economy Observatory- Cluster Monitor.

Maggioni, M. A. (2002). Clustering dynamics and the location of high-tech-firms. ( $1^{\text {st }}$ Ed.). Physica-Verlag HD. http://dx.doi.org/10.1007/978-3-642-57480-1

Maggioni, M. A. (2004). The rise and fall of industrial clusters: Technology and the life cycle of region. Working Papers from Institut d'Economia de Barcelona (IEB), 6. Barcelona.

Maggioni, M. A., \& Riggi, M. R. (2008). High-tech firms and the dynamics of innovative industrial clusters. In C. Karlsson (Eds.), Handbook of Research on Innovation and Clusters, (pp. 54-78). UK. Northampton, MA. USA: Edward Elgar Publishing, Inc. Cheltenham.

Maskell, P., \& Kebir, L. (2005). What qualifies as a cluster theory? DRUID Working Paper, 05-09. Copenhagen: Department of Industrial Economics and Strategy. Copenhagen Business School. 
Menzel, M.P., \& Fornahl, D. (2006). Cluster life cycles. Proceedings of Entrepreneurship, knowledge, learning and the evolution of industrial/territorial clusters and regions. November $30^{\text {th }}$ - December $1^{\text {st }} 2006$. Athens, Greece.

Menzel, M. P., \& Fornahl, D. (2007). Cluster life cycles - Dimensions and rationales of cluster development. Proceedings of the DRUID-DIME Academy Winter 2007 Ph.D Conference on Geography, Innovation and Industrial Dynamics. Denmark.

Menzel, M. P., \& Fornahl, D. (2009). Cluster life cycles - Dimensions and rationales of cluster evolution. Industrial and Corporate Change, 19(1), 205-238. Oxford University Press on behalf of Associations ICC. http://dx.doi.org/10.1093/icc/dtp036

Ministry of Industry Republic Indonesia (2001). Strategy of National Industry. Jakarta.

Nadvi, K., \& Barrientos, S. (2004). Industrial Clusters and poverty reduction, towards a methodology for poverty and social impact assessment of cluster development initiatives. UNIDO.

Niu, K. H., Miles, G., \& Lee, C. S. (2008). Strategic development of network clusters. a study of high technology regional and global competitiveness. Competitiveness Review: An International Business Journal, 18, 176-191. http://dx.doi.org/10.1108/10595420810905966

Okoli, C., \& Pawlowski, S. (2004). The Delphi Method as a research tool: An example, design considerations and applications. Information and Management, 42(1), 15-29. http://dx.doi.org/10.1016/j.im.2003.11.002

Parung, J., \& Bititci, U. S. (2008). A metric for collaborative networks. Business $\begin{array}{llll}\text { Process Management Journal, } 14 \quad \text { (5), } & \text { 654-674. }\end{array}$ http://dx.doi.org/10.1108/14637150810903048

Porter, M.E. (1985). Competitive Advantage, Creating and Sustaining Superior Performance. New York: The Free Press.

Porter, M.E. (1990). The Competitive Advantage of Nations. New York.

Porter, M.E., \& Schwab, K. (2008). The Global Competitiveness Report 2008-2009. Switzerland: World Economic Forum.

Press, K. (2006). A Life cycle for clusters? The dynamics of agglomeration, change, and adaptation. Germany: A Physica-Verlag Heidelberg Springer Company. 
Raco, M. (1999). Competition, collaboration and the new industrial districts: Examining the institutional turn in local economic development. Urban Studies, 36, 951-968. http://dx.doi.org/10.1080/0042098993295

Rocha, H. O. (2004). Entrepreneurship and development: The role of clusters. Small Business Economics, 23(5), 363-400. http://dx.doi.org/10.1007/s11187-0043991-8

Schmitz, H., \& Musyck, B. (1994). Industrial Districts in Europe: Policy Lessons for Developing Countries? World Development, 22(6), 889-910. http://dx.doi.org/10.1016/0305-750x(94)90060-4

Schmitz, H. (1995). Collective efficiency: Growth path for small scale industry. The Journal of Development Studies, 31(4), 529-566. http://dx.doi.org/10.1080/00220389508422377

Schwab, K. (2010). The Global competitiveness report 2010-2011. Switzerland: World Economic Forum.

Segil, L. (2004). Measuring the value of partnering, how to use metrics to plan, develop, and implement successful alliances. New York: Amacom.

Shields, M., Barkley, D., \& Emery, M. (2004). Industry clusters and industry targeting. Industry Targeting Workshop, Orlando, Florida. December 2-3, 2004.

Tambunan, M., \& Hillebrand, W. (2001). Institutional set-up for SME policy design and implementation case study Japan. ADB SME Technical Assistance.

Thangaritinam, S., \& Redman, C. W. E. (2005). The Delphi technique. Education $\begin{array}{llll}\text { the Obstetrician } \quad \text { \& } & \text { Gynaecologist, }\end{array}$ http://dx.doi.org/10.1576/toag.7.2.120.27071

Ulhaque, I. (1995). Trade, technology, and international competitiveness. EDI Development Studies. Washington D.C: The World Bank.

Wolter, K. (2003). A Life cycle for clusters? The Dynamics governing regional agglomerations. Proceedings of the Conference on Clusters, Industrial Districts and Firms: the Challenge of Globalization, Modena. Italy. September 12-13, 2003.

Woodward, D., \& dan Guimarães, P. (2009). Porter's cluster strategy and industrial targeting in targeting regional economic development. Routledge. 
Journal of Industrial Engineering and Management, 2012 (www.jiem.org)

(c)

SORIERIGHIS RESERVED

Article's contents are provided on a Attribution-Non Commercial 3.0 Creative commons license. Readers are allowed to copy, distribute and communicate article's contents, provided the author's and Journal of Industrial Engineering and Management's names are included. It must not be used for commercial purposes. To see the complete license contents, please visit http://creativecommons.org/licenses/by-nc/3.0/. 